\title{
Methanol extract from Vietnamese Caesalpinia sappan induces apoptosis in HeLa cells
}

Tran Manh Hung ${ }^{1 *}$, Nguyen Hai Dang ${ }^{2}$ and Nguyen Tien Dat ${ }^{2}$

\begin{abstract}
Background: This study evaluated the cytotoxic activity of extracts from Caesalpinia sappan heartwood against multiple cancer cell lines using an MTT cell viability assay. The cell death though induction of apoptosis was as indicated by DNA fragmentation and caspase-3 enzyme activation.

Results: A methanol extract from C. sappan (MECS) showed cytotoxic activity against several of the cancer cell lines. The most potent activity exhibited by the MECS was against HeLa cells with an $I C_{50}$ value of $26.5 \pm 3.2 \mu \mathrm{g} / \mathrm{mL}$. Treatment of HeLa cells with various MECS concentrations resulted in growth inhibition and induction of apoptosis, as indicated by DNA fragmentation and caspase-3 enzyme activation.

Conclusion: This study is the first report of the anticancer properties of the heartwood of $C$. sappan native to Vietnam. Our findings demonstrate that C. sappan heartwood may have beneficial applications in the field of anticancer drug discovery.
\end{abstract}

Keywords: Caesalpinia sappan, Leguminosae, MTT assay, DNA fragmentation, Caspase-3

\section{Background}

Apoptosis is a form of cell death that occurs in organisms under pathological conditions and contributes to cell replacement, tissue remodeling, and removal of damaged cells under normal conditions [1]. Therapies designed to enhance or decrease the susceptibility of individual cell types to apoptosis could provide a basis for the treatment of a variety of human diseases [2]. However, inappropriate regulation of apoptosis can cause serious disorders, such as neural degeneration, autoimmune disease, and cancer $[3,4]$. Natural products with apoptotic activity have attracted a great deal of attention as potential new sources of leads for anti-cancer drugs. Various phytochemicals from medicinal plants have been shown to exert antitumoric effects via apoptosis.

Caesalpinia sappan L. (Leguminosae) is widely distributed in Southeast Asia. It has been used as an herbal medicine for treatment of inflammation and improvement of blood circulation [5], and as an anti-influenza, antiallergic, and neuroprotective medication [6-8]. C. sappan,

\footnotetext{
* Correspondence: tmhung801018@gmail.com

${ }^{1}$ Faculty of Chemistry, University of Science, Vietnam National University-HoChiMinh City, 227 Nguyen Van Cu, District 5, HoChiMinh City, Vietnam

Full list of author information is available at the end of the article
}

called "Tô Mộc" in Vietnam, is dispersed across low mountainous areas, requires high light, and is drought-tolerant. "Tô Mộc" was used in Vietnamese traditional medicine for treatment of menstrual and postpartum hematometra, trauma blood static, dizziness, and postpartum blood losses. It was also used in therapy for bloody dysentery, enteralgia, intestinal hemorrhage, and infectious diarrhea and for washing wounds [9]. The major active components in $C$. sappan are phenolics of four structural subtypes: brazilin, chalcone, protosappanin, and homoisoflavonoids [10-15]. An ethanol extract of $C$. sappan ameliorated hypercholesterolemia in C57BL/6 mice and suppressed inflammatory responses in human umbilical vein endothelial cells (HUVECs) through an antioxidant mechanism [11]. Compounds with a sappanchalcone skeleton exhibited antiinflammatory, antibacterial, and antiinfluenza activities [12-15]. Nguyen et al. reported that a methanol extract and the active compounds from C. sappan heartwood collected in Vietnam exhibited significant xanthine oxidase (XO) inhibitory activity $[16,17]$. However, limited information is available concerning the anticancer activity of C. sappan originated from Vietnam. In this study, we investigated in vitro the anticancer properties, including antiproliferation activity and apoptosis induction, of a methanol extract from Vietnamese C. sappan heartwood. 


\section{Results and discussion}

The methanol, ethanol, and water extract yields from $C$. sappan heartwood were $18.8,20.5$, and $15.6 \%$, respectively (Table 1). Multiple cancer cell lines were used to evaluate the potential inhibitory effects of these extracts on cell growth. Cancer cells were seeded in 96-well plates, incubated for $4 \mathrm{~h}$, and then treated with various concentrations $(5-100 \mu \mathrm{g} / \mathrm{mL})$ of the extracts or with the standard anticancer drug, adryamicin. Cytotoxic effects were assessed using an MTT cell viability assay [18]. The methanol and ethanol extracts showed cytotoxic activity against HeLa cells with $\mathrm{IC}_{50}$ values of $26.5 \pm 3.2$ and $39.2 \pm 3.0 \mu \mathrm{g} / \mathrm{mL}$, respectively (Table 2). The methanol extract also exhibited significant cytotoxic activity against HL-60, MCF-7, HepG2, and $\mathrm{KB}$ cancer cells with $\mathrm{IC}_{50}$ values of $40.7 \pm 2.8,37.7 \pm$ $1.1,65.1 \pm 3.5$, and $76.7 \pm 4.1 \mu \mathrm{g} / \mathrm{mL}$, respectively. The ethanol extract displayed cytotoxicity against HL-60 and LLC cells with $\mathrm{IC}_{50}$ values of $68.5 \pm 5.1$ and $39.2 \pm 2.0 \mu \mathrm{g} / \mathrm{mL}$, respectively. The water extract showed weak cytotoxicity against all cancer cell lines, except for HeLa cells, with an $\mathrm{IC}_{50}$ value of $37.8 \pm 3.6 \mu \mathrm{g} / \mathrm{mL}$ (Table 2). Because the methanol extract (MECS) exhibited the most potent cytotoxic activity, it was selected for further evaluation of its inhibition of HeLa cell proliferation. Cells were treated with MECS (5-100 $\mu \mathrm{g} / \mathrm{mL})$, incubated for 7 days, and counted at 2-day intervals using the trypan blue exclusion method. The growth of cells treated with MECS $(10 \mu \mathrm{g} / \mathrm{mL})$ was significantly inhibited by $38.4 \pm 5.2 \%$ after 3 days relative to control cells. When the concentration of MECS was increased to 20,50 , or $100 \mu \mathrm{g} / \mathrm{mL}$, the percentage of inhibition was increased to $78.7 \pm 6.5,86.4 \pm 3.6$, or $95.8 \pm 1.0 \%$, respectively, after 7 days of incubation (data not shown).

To evaluate whether the inhibition of HeLa cell growth by MECS was mediated by apoptosis, we performed a DNA laddering assay [19]. Chromosomal DNA extracted from cells treated with 10,20 , or $50 \mu \mathrm{g} / \mathrm{mL}$ MECS for $24 \mathrm{~h}$ exhibited internucleosomal DNA fragmentation consisting of multiple fragments approximately 180-200 base pairs in size as visualized by agarose gel electrophoresis. At higher MECS concentrations, 20 and $50 \mu \mathrm{g} / \mathrm{mL}$, internucleosomal DNA fragmentation was also observed after 36- and 48-h incubations (Figure 1).

Caspase- 3 is a cytosolic protein that normally exists as a $32-\mathrm{kDa}$ inactive precursor, which undergoes proteolytic cleavage into a heterodimer during apoptosis. Caspase-3

\section{Table 1 Percentage yields of extracts ( $\% \mathrm{w} / \mathrm{w})$}

\begin{tabular}{lc}
\hline Plant extracts & Percentage yield (\%) \\
\hline MeOH ex. & $18.8 \pm 5.4$ \\
EtOH ex. & $20.5 \pm 4.7$ \\
Water ex. & $15.6 \pm 7.5$ \\
\hline
\end{tabular}

${ }^{\mathrm{a}}$ Data are presented as the mean \pm SD of results from three independent experiments. activity was determined by the amount of proteolytic cleavage of Ac-Asp-Glu-Val-Asp-8-amino-4-trifluoromethylcoumarin (Av-DEVD-AFC) [18] in HeLa cells after 12, 24, or $48 \mathrm{~h}$ treatment with MECS $(5,10,20,50$, or $100 \mu \mathrm{g} / \mathrm{mL})$. The caspase- 3 activity increased by one- to six-fold in dose- and time-dependent manner relatives to the control (Figure 2).

Induction of apoptosis is a useful strategy in cancer therapies and is an important property of candidate anticancer drugs that distinguishes them from toxic compounds. Much effort has been directed into the search for compounds that influence apoptosis and to understanding their mechanisms of action. In this study, we showed that MECS exhibited a potent inhibitory activity against various cancer cell lines, especially against HeLa cells, through the induction of apoptosis. The C. sappan extract caused cell death by increasing the duration of the sub-G1 phase of the cell cycle and the condensation and shrinkage of nuclei in HNSCC4 and HNSCC31 (head and neck) cancer cell lines [20]. Among the compounds isolated from C. sappan, isoliquiritigenin 2'-methyl ether inhibited the growth of oral cancer cells via a pathway involving MAP kinases, NF- $\mathrm{kB}$, and Nrf2 [21]. Sappanchalcone, a flavonoid, suppressed oral cancer cell growth and induced apoptosis through the activation of p53-dependent mitochondrial p38, ERK, JNK, and NF- $\mathrm{kB}$ signaling [22]. Brazilein, a major phenolic compound from C. sappan, exhibited antioxidant activity, inhibited intracellular lipid accumulation during adipocyte differentiation in 3 T3-L1 cells, and suppressed the induction of peroxisome proliferator-activated receptor $\gamma$ [23]. The toxic effects of brazilein were evaluated in terms of cell viability, induction of apoptosis, and caspase- 3 activity in BCC cells [23]. Brazilein also showed dose-dependent inhibition of cell proliferation and induction of apoptosis in glioma cells by increasing the proportion of cleaved poly(ADP)-ribose polymerase and by decreasing caspase- 3 and caspase-7 expression [24].

This study showed that addition of methanol (MECS), ethanol, and water extracts of C. sappan heartwood to growth medium decreased the HeLa cell population. Treatment with MECS induced apoptosis, thereby inhibiting HeLa cell growth. Further biochemical analysis indicated that the inhibitory activity of MECS against proliferation was related to the induction of apoptosis. Cultured HeLa cells treated with MECS $(5-100 \mu \mathrm{g} / \mathrm{mL})$ exhibited morphological features typical of apoptosis, which was consistent with the dose- and time-dependent DNA fragmentation, as determined by agarose gel electrophoresis (Figure 1). Several caspases play important roles in the regulation of apoptosis. They are grouped broadly as initiator or effector caspases according to the roles they play in inducing the apoptotic system. The initiator caspases include caspase- $1,-8$, and -9 . Caspase- 8 and -9 are typically activated by two alternative pathways. The first 
Table 2 Cytotoxic activity of extracts from C. sappan

\begin{tabular}{lcccccccc}
\hline Extracts & \multicolumn{7}{c}{ IC $_{\mathbf{5 0}}$ value $(\boldsymbol{\mu g} / \mathbf{m L})^{\mathbf{a}}$} \\
\cline { 2 - 8 } & HL-60 & HeLa & MCF7 & LLC & HepG2 & KPL4 & HT-29 & KB \\
\hline MeOH ex. & $40.7 \pm 5.8$ & $26.5 \pm 3.2$ & $37.7 \pm 3.1$ & $>100$ & $65.1 \pm 3.5$ & $>100$ & $>100$ & $76.7 \pm 4.8$ \\
EtOH ex. & $68.5 \pm 5.1$ & $39.2 \pm 2.0$ & $>100$ & $25.1 \pm 3.8$ & $>30$ & $>100$ & $>100$ & $>100$ \\
Water ex. & $>100$ & $37.8 \pm 3.6$ & $>100$ & $>100$ & $78.6 \pm 4.3$ & $>100$ & $>100$ & $>100$ \\
Camptothecin $^{b}$ & $6.2 \pm 0.2$ & $3.4 \pm 0.2$ & $4.5 \pm 0.3$ & $5.1 \pm 0.7$ & $6.2 \pm 0.4$ & $14.5 \pm 1.7$ & $10.7 \pm 0.8$ & $4.5 \pm 0.4$ \\
\hline
\end{tabular}

${ }^{\mathrm{a}}$ The inhibitory effects are represented as giving $50 \%$ inhibition $\left(\mathrm{IC}_{50}\right)$ relative to the vehicle control. These data represent the average values of three repeated experiments (mean \pm S.D.).

${ }^{\mathrm{b}}$ Positive control.

involves cell death receptor-mediated apoptosis via caspase- 8 and is characterized by binding of cell death ligands and cell death receptors and subsequent activation of caspase- 8 and -3 . The second pathway involves mitochondria-mediated apoptosis via caspase-9. In both pathways, caspase- 3 activation plays a central role in the initiation of apoptosis [25]. MECS concentrations of $5-100 \mu \mathrm{g} / \mathrm{mL}$ induced caspase- 3 activation in dose- and time-dependent manners (Figure 2). Many models of apoptosis include loss of mitochondrial transmembrane potential mediated by opening of the mega-channel, which precedes caspase activation. Caspase-3 activation is required for several typical hallmarks of apoptosis and is indispensable for apoptotic chromatin condensation and DNA fragmentation.

\section{Conclusion}

This study for the first time determined that MECS effectively inhibit the proliferation of HeLa cells by mechanism involved the induction of apoptosis. According to these results, it is suggested that the methanol extract of Vietnamese C. sappan may be a considerable source for the development of anti-cancer drugs. Further investigation to determine its bioactive components is currently in progress.

\section{Methods}

Plant material

The heartwood of Caesalpinia sappan L. was collected in An Giang province, Vietnam, in September 2010. Professor Tran Cong Luan at Vietnam National Institute of Medicinal Material botanically authenticated the plant. A voucher specimen number TCL-00120 describing the plant was deposited at the institute.

\section{Extract preparation}

The extracts were prepared according to World Health Organization protocol (CG-1983) with a slight modification. The plant was dried and powdered, $50 \mathrm{~g}$ powder was extracted with $500 \mathrm{~mL}$ of methanol, ethanol or distilled water ( 3 times) for 3 hours under reflux. After extractions, the extracts were combined and filtered with Whatman filter paper No.1, and then were concentrated in vacuo to dryness. All extracts were stored at $-4^{\circ} \mathrm{C}$ until use.

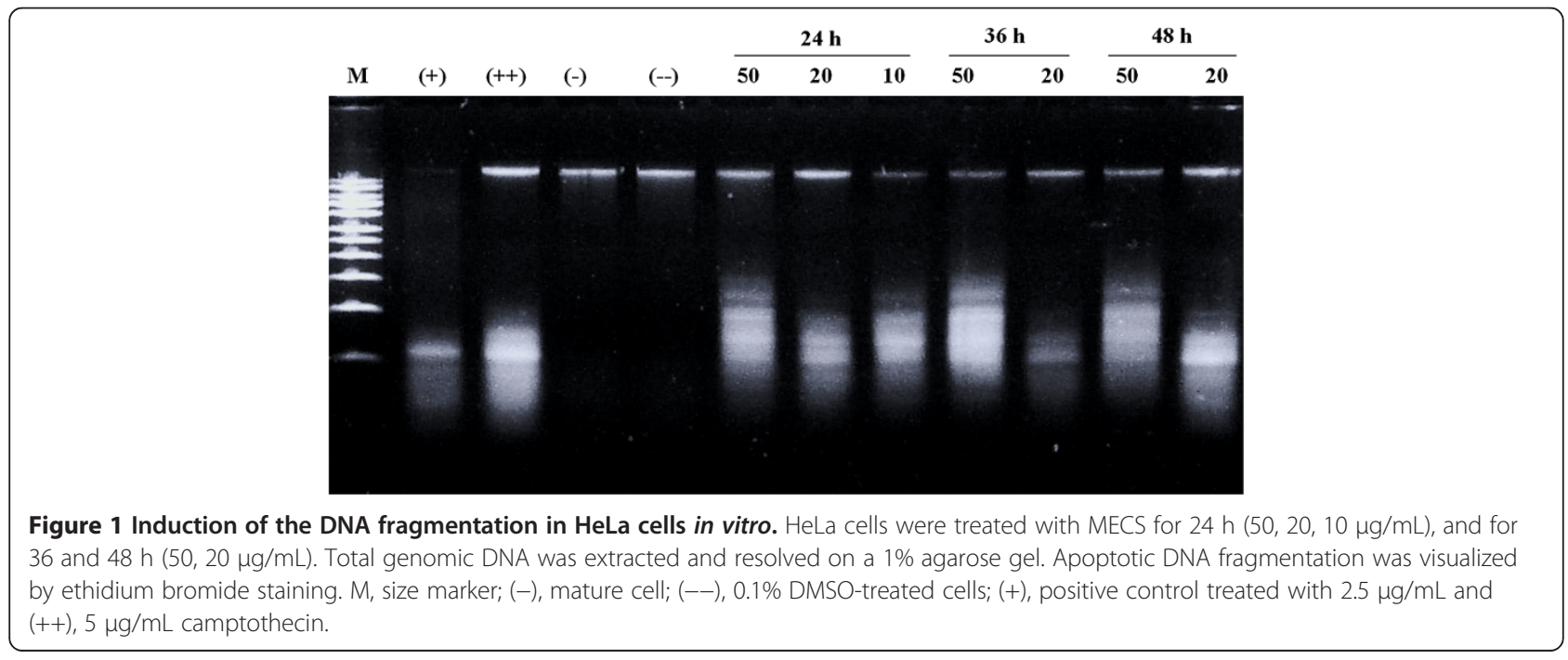




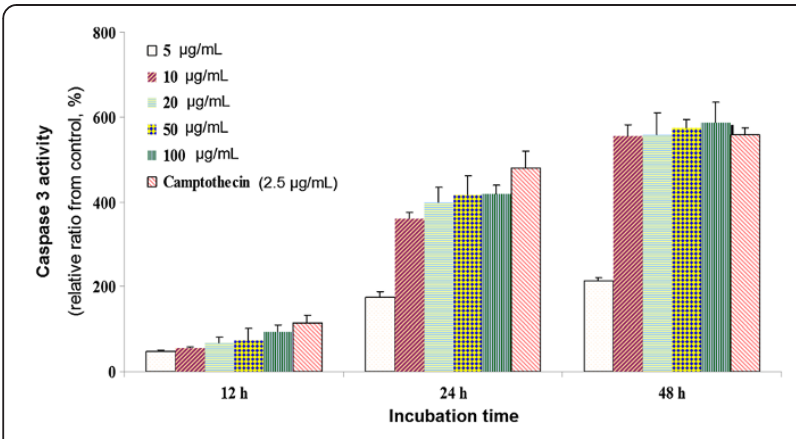

Figure 2 The increment of caspase-3 activity in HeLa cells in vitro. After 12, 24 and $48 \mathrm{~h}$ incubation with MECS, HeLa cells lysates were incubated at $37^{\circ} \mathrm{C}$ with caspase-3 substrate (Ac-DEVD-AFC) for $1 \mathrm{~h}$. The fluorescence intensity of the cell lysates was measured to determine the caspase-3 activity. The blank group was used as $0.1 \%$ DMSO-treated cells; Camptothecin $(2.5 \mu \mathrm{g} / \mathrm{mL})$ was used as positive control. Data are presented as the mean \pm S.D. of results from three independent experiments (* $P<0.05$ vs. control).

\section{Cell lines and culture}

HL-60 (human promyelocytic leukemia), HeLa (human cervical adenocarcinoma), MCF-7 (human breast adenocarcinoma), LLC (lewis lung carcinoma), HepG2 (liver hepatocellular cells), KPl4 (human breast cancer), HT-29 (human colon carcinoma) and KB (mouth epidermal carcinoma) cells were obtained from the American Type Culture Collection (ATCC). The cells were maintained in RPMI or IMDM (GibcoBRL, NY, USA) with $10 \%$ fetal bovine serum (FBS) supplemented with $2 \%$ penicillin and $100 \mu \mathrm{g} / \mathrm{mL}$ of streptomycin at $37^{\circ} \mathrm{C}$ in a humidified atmosphere containing $5 \% \mathrm{CO}_{2}$.

\section{Cytotoxic activity assay}

The cancer cell lines were maintained in RPMI 1640 or IMDM that included L-glutamine (GIBCO) with $10 \% \mathrm{FBS}$ (GIBCO) and $2 \%$ penicillin-streptomycin (GIBCO). Cells were cultured at $37^{\circ} \mathrm{C}$ in a $5 \% \mathrm{CO}_{2}$ incubator. Cytotoxic activity was measured using a modified MTT assay [18]. Viable cells were seeded in the growth medium into 96well microtiter plates $\left(1 \times 10^{4}\right.$ cells/well $)$ and were incubated at $37^{\circ} \mathrm{C}$ in a $5 \% \mathrm{CO}_{2}$ incubator. A test sample was dissolved in DMSO and was adjusted to final sample concentrations ranging from 5 to $100 \mu \mathrm{g} / \mathrm{mL}$ by diluting with the growth medium. Each sample was prepared in triplicate. The final DMSO concentration was adjusted to $<0.1 \%$. After standing for $24 \mathrm{~h}$, the test sample was added to each well. The same volume of medium with $0.1 \%$ DMSO was added to the control wells. $48 \mathrm{~h}$ after the addition of the test sample, MTT reagent was added to each well (final concentration: $5 \mu \mathrm{g} / \mathrm{mL}$ ). $4 \mathrm{~h}$ later, the plate was centrifuged for $5 \mathrm{~min}$ at $1500 \mathrm{rpm}$, the medium was removed, and the resulting formazan crystals were dissolved in DMSO. The optical density (OD) was measured at $570 \mathrm{~nm}$ using a Titertek microplate reader (Multiskan MCC/340, Flow). The $\mathrm{IC}_{50}$ value was defined as the concentration of sample which reduced absorbance by $50 \%$ relative to the vehicletreated control.

\section{DNA gel electrophoresis (DNA laddering)}

DNA from the cells was purified by using an Apoptotic DNA Ladder Kit (Roche, Germany), and DNA bands were photographed under ultraviolet illumination [19]. HeLa cells $\left(5 \times 10^{5}\right.$ cell $\left./ \mathrm{mL}\right)$ were treated with the indicated concentration of tested extract for $24 \mathrm{~h}$. After the supernatant was removed by centrifugation $\left(1500 \mathrm{rpm}, 4^{\circ} \mathrm{C}\right)$, the cells were washed with $1 \mathrm{~mL}$ of PBS and was precipitated by centrifugation at $3000 \mathrm{rpm}$ for $10 \mathrm{~min}$ at $4^{\circ} \mathrm{C}$. DNA from the cells was purified by using an Apoptotic DNA Ladder Kit and was separated on $1 \%(\mathrm{w} / \mathrm{v})$ agarose gel containing $2.5 \mu \mathrm{L}$ of $10 \mathrm{mg} / \mathrm{mL}$ ethidium bromide in TBE buffer [0.045 M Tris-borate (pH 8.0), 0.001 M EDTA].

\section{Caspase-3 activity}

Caspase-3 enzyme activity was measured by proteolytic cleavage of the fluorogenic substrate Ac-DEVD-AFC by counting on a fluorescence plate reader (Twinkle LB970 microplate fluorometer, Berthold Technologies, Germany). HeLa cells $\left(1 \times 10^{5}\right.$ cell/well $)$ were treated with plant extract at concentrations of 5, 12.5, 25, 50 and $100 \mu \mathrm{g} / \mathrm{mL}$. After incubation for $24 \mathrm{~h}$, cells were harvested and washed with cold PBS. The pellets were lyzed using $15 \mu \mathrm{L}$ of lysis buffer [10 mM Tris-HCl (pH 8.0), 10 mM EDTA, 0.5\% Triton X-100] at room temperature for $10 \mathrm{~min}$, and then placed on ice; $100 \mu \mathrm{L}$ of assay buffer $[100 \mathrm{mM}$ Hepes (pH 7.5), $10 \mathrm{mM}$ dithiothreitol, $10 \%(\mathrm{w} / \mathrm{v})$ sucrose, $0.1 \%$ (v/v) Chaps, $0.1 \%(\mathrm{v} / \mathrm{v}) \mathrm{BSA}$ ] and $10 \mu \mathrm{L}$ of substrate solution (200 $\mu \mathrm{M}$ substrate in assay buffer) were added. After incubation at $37^{\circ} \mathrm{C}$ for $1 \mathrm{~h}$, fluorescence was measured with excitation at $370 \mathrm{~nm}$ and emission at $505 \mathrm{~nm}$ [18].

\section{Statistical analysis}

The results are expressed as mean value \pm S.D. Statistical analysis was performed using one-way ANOVA. A $P<$ 0.05 was considered statistically significant.

\section{Competing interests}

The authors declare that they have no competing interests.

\section{Authors' contributions}

TMH carried out conception and design of the study, acquisition of data, /analysis and interpretation of data, drafting the manuscript and revising. NHD and NTD carried out acquisition of data, analysis and interpretation of data, statistical analysis. All authors read and approved the final manuscript.

\section{Acknowledgments}

This research is funded by Vietnam National Foundation for Science and Technology Development (NAFOSTED) under grant number 106.05-2011.52. 


\section{Author details}

${ }^{1}$ Faculty of Chemistry, University of Science, Vietnam National

University-HoChiMinh City, 227 Nguyen Van Cu, District 5, HoChiMinh City, Vietnam. ${ }^{2}$ Institute of Marine Biochemistry, Vietnam Academy of Science and Technology (VAST), 18 Hoang Quoc Viet, Caugiay District, Hanoi, Vietnam.

Received: 20 May 2014 Accepted: 20 May 2014

Published: 27 May 2014

\section{References}

1. De-Long MJ: Apoptosis: a modulator of cellular homeostasis and disease states. Ann N Y Acad Sci 1988, 842:82-90.

2. Bold RJ, Termuhlen PM, Mcconkey DJ: Apoptosis, cancer and cancer therapy. Surg Oncol 1997, 6:133-142.

3. Earnshaw WC, Martins LM, Kaufman SH: Mammalian caspases: structure, activation, substrates, and functions during apoptosis. Annu Rev Biochem 1999, 68:383-424.

4. Bursch W, Oberhammer F, Schulte-Hermann R: Cell death by apoptosis and its protective role against disease. Trends Pharmacol Sci 1992, 13:245-251.

5. Nagai M, Nagumo S, Eguchi I, Lee SM, Suzuki T: Sappanchalcone from Caesalpinia sappan L., the proposed biosynthetic precursor of brazilin. Yakugaku Zasshi 1984, 104:935-938.

6. Liu AL, Shu SH, Qin HL, Lee SM, Wang YT, Du GH: In vitro anti-influenza viral activities of constituents from Caesalpinia sappan. Planta Med 2009, 75:337-339

7. Yodsaoue $\mathrm{O}$, Cheenpracha S, Karalai C, Ponglimanont C, Tewtrakul S: Antiallergic activity of principles from the roots and heartwood of Caesalpinia sappan on antigen-induced beta-hexosaminidase release. Phytother Res 2009, 23:1028-1031.

8. Shen J, Zhang H, Lin H, Su H, Xing D, Du L: Brazilein protects the brain against focal cerebral ischemia reperfusion injury correlating to inflammatory response suppression. Eur J Pharmacol 2007, 558:88-95.

9. Bich DH: Selected Medicinal Plants in Vietnam, Volume 1. Hanoi: Science and Technology Publishing House; 1999:151-154.

10. Shimokawa T, Kinjo J, Yamahara J, Yamasaki M, Nohara T: Two novel compounds from Caesalpinia sappan L. Chem Pharm Bull 1985, 33:3545-3547.

11. Choi BM, Lee JA, Gao SS, Eun SY, Kim YS, Ryu SY, Choi YH, Park R, Kwon DY, Kim BR: Brazilin and the extract from Caesalpinia sappan L. protect oxidative injury through the expression of heme oxygenase-1. Biofactors 2007, 30:149-157.

12. Namikoshi M, Nakata H, Saitoh T: Study on the chemical constituents of Caesalpinia sappan. Chem Pharm Bull 1987, 35:3615-3619.

13. Kim B, Kim SH, Jeong SJ, Sohn EJ, Jung JH, Lee MH, Kim SH: Brazilin induces apoptosis and G2/M arrest via inactivation of histone deacetylase in multiple myeloma U266 cells. J Agric Food Chem 2012, 60:9882-9889.

14. Lee MJ, Lee HS, Jung HJ, Lee CS, Kim JE, Moon HI, Park WH: Caesalpinia sappan L. ameliorates hypercholesterolemia in C57BL/6 mice and suppresses inflammatory responses in human umbilical vein endothelial cells (HUVECs) by antioxidant mechanism. Immunopharmacol Immunotoxicol 2010, 32:671-679.

15. Washiyama M, Sasaki Y, Hosokawa T, Nagumo S: Anti-inflammatory constituents of Sappan Lignum. Biol Pharm Bull 2009, 32:941-944.

16. Nguyen MT, Awale S, Tezuka Y, Tran QL, Kadota S: Neosappanone A, a xanthine oxidase $(\mathrm{XO})$ inhibitory dimeric methanodibenzoxocinone with a new carbon skeleton from Caesalpinia sappan. Tetrahedron Lett 2004, 45:8519-8522.

17. Nguyen MT, Awale S, Tezuka Y, Tran QL, Watanabe H, Kadota S: Xanthine oxidase inhibitory activity of Vietnamese medicinal plants. Biol Pharm Bull 2004, 27:1414-1421.

18. Lee MK, Hung TM, Cuong TD, Na M, Kim JC, Kim EJ, Park HS, Choi JS, Lee I, Bae K, Hattori M, Min BS: Ergosta-7,22-diene-23,3a,9a-triol from the fruit bodies of Ganoderma lucidum induces apoptosis in human myelocytic HL-60 cells. Phytother Res 2011, 25:1579-1585.

19. Kwon HJ, Bae SY, Kim KH, Han CH, Cho SH, Nam SW, Choi YH, Kim BW: Induction of apoptosis in HeLa cells by ethanolic extract of Corallina pilulifera. Food Chem 2007, 104:196-201.

20. Kim EC, Hwang YS, Lee HJ, Lee SK, Park MH, Jeon BH, Jeon CD, Lee SK, Yu HH, You YO: Caesalpinia sappan induces cell death by increasing the expression of p53 and p21WAF1/CIP1 in head and neck cancer cells. Am J Chin Med $2005,33: 405-414$
21. Lee $Y M$, Jeong GS, Lim HD, Ahn RB, Kim YC, Kim EC: Isoliquiritigenin 2'-methyl ether induces growth inhibition and apoptosis in oral cancer cells via heme oxygenase-1. Toxicol In Vitro 2010, 24:776-782.

22. Lee YM, Kim YC, Choi BJ, Lee DW, Yoon JH, Kim EC: Mechanism of sappanchalcone-induced growth inhibition and apoptosis in human oral cancer cells. Toxicol In Vitro 2011, 25:1782-1788.

23. Liang CH, Chan LP, Chou TH, Chiang FY, Yen CM, Chen PJ, Ding HY, Lin RJ: Brazilein from Caesalpinia sappan L. Antioxidant inhibits adipocyte differentiation and induces apoptosis through caspase-3 activity and anthelmintic activities against Hymenolepis nana and Anisakis simplex. Evid Based Complement Alternat Med 2013, 2013:864-892.

24. Yen CT, Nakagawa-Goto K, Hwang TL, Wu PC, Morris-Natschke SL, Lai WC, Bastow KF, Chang FR, Wu YC, Lee KH: Antitumor agents. 271: Total synthesis and evaluation of brazilein and analogs as anti-inflammatory and cytotoxic agents. Bioorg Med Chem Lett 2010, 20:1037-1039.

25. Salvesen GS, Dixit VM: Caspase activation: the induced-proximity model Proc Natl Acad Sci U S A 1999, 96:10964-10967.

doi:10.1186/0717-6287-47-20

Cite this article as: Hung et al:: Methanol extract from Vietnamese Caesalpinia sappan induces apoptosis in HeLa cells. Biological Research 2014 47:20.

\section{Submit your next manuscript to BioMed Central and take full advantage of:}

- Convenient online submission

- Thorough peer review

- No space constraints or color figure charges

- Immediate publication on acceptance

- Inclusion in PubMed, CAS, Scopus and Google Scholar

- Research which is freely available for redistribution 